Bull. Chem. Soc. Ethiop. 2013, 27(1), 35-47.

Printed in Ethiopia

ISSN 1011-3924

DOI: http://dx.doi.org/10.4314/bcse.v27i1.4

\title{
REMOVAL OF Ni(II) FROM AQUEOUS SOLUTION USING LEAF, BARK AND SEED OF MORINGA STENOPETALA ADSORBENTS
}

\author{
Beyene Hagos Aregawi and Alemayehu Abebaw Mengistie ${ }^{*}$ \\ College of Natural and Computational Science, Department of Chemistry \\ Ambo University, P.O. Box 19 Ambo, Ethiopia
}

(Received December 14, 2011; revised November 13, 2012)

\begin{abstract}
The present study investigates the possibility of using leaf, bark and seed of Moringa stenopetala as alternative adsorbents for removal of $\mathrm{Ni}$ (II) from aqueous solutions. The optimum adsorption conditions for removal of $\mathrm{Ni}$ (II) were found to be 30,20 and $50 \mathrm{mg} / \mathrm{L}$ initial concentration, $1.5,2$ and $2.5 \mathrm{~g}$ adsorbent dose, 250, 250 and $300 \mathrm{rpm}$ agitation speed, 90,120 and 90 min contact time, 40,30 and $23{ }^{\circ} \mathrm{C}$ temperature and $\mathrm{pH}$ of 5, 6 and 6 using leaf, bark and seed as adsorbent, respectively. At optimum experimental conditions the percent adsorption of synthetic wastewater sample was found to be $93.90,96.25$ and 97.50 for leaf, bark and seed, respectively. The tested experimental data best fits to pseudo-second order $\left(\mathrm{R}^{2}>0.98\right)$ than pseudo-first order, Elovich and intraparticle diffusion kinetic models indicating rate limiting step to be chemisorption. It also fits to Langmuir $\left(\mathrm{R}^{2}>0.895\right.$ using adsorbate variation and also $\mathrm{R}^{2}>0.998$ using both time and temperature variation data) than Freundlich, Temkin and D-R isotherm models. D-R isotherm and thermodynamic study reveals formation of physical adsorption. Hence the adsorption mechanism could be regarded as physico-chemical adsorption process. The adsorption results of industrial wastewater also reveal that for removal of nickel $83 \%$ and $85 \%$ was obtained using bark and seed adsorbents, respectively. The new method of adsorption developed in this study is cheap, fast and environmental friendly.
\end{abstract}

KEY WORDS: Moringa stenopetala, Ni(II) adsorption, Isotherms, Kinetics, Thermodynamics, Industrial wastewater

\section{INTRODUCTION}

Pollution load of the environment is increasing due to global rise in population and our quest to lead comfortable life resulting in explosive growth of industrial and agricultural activities. Environmental contamination with metal ions represents a potential threat to human, animals and plants. Metal ions which many of them are soluble in aqueous solutions become more available for living systems and accumulate in the environment are of vital concern $[1,2]$.

Nickel is released into the environment in a large number of processes such as electroplating and steel manufacturing. High nickel concentrations on sandy soils can clearly damage plants and high nickel concentrations in surface waters can diminish the growth rates of algae and microorganisms. Nickel is present in wastewaters from metal processing, steel foundry, motor vehicle and aircraft, leather and chemical industries [3].

Humans may be exposed to nickel by breathing air, drinking water, eating food or smoking cigarettes. Skin contact with nickel-contaminated soil or water may also result in nickel exposure. Small amounts of nickel are needed by the human body to produce red blood cells, however, in excessive amounts can become mildly toxic. Short-term overexposure to nickel is not known to cause any health problems, but long-term exposure can cause decreased body weight, heart and liver damage and skin irritation. Nickel may cause dermatitis upon exposure to the skin, and gastrointestinal distress upon ingestion. In India, the acceptable limit of $\mathrm{Ni}$ (II) in drinking water is $0.01 \mathrm{mg} / \mathrm{L}$ and $2.0 \mathrm{mg} / \mathrm{L}$ is the industrial discharge limit in waste water $[4,5]$.

Some of the techniques which have been used in the removal of metals from effluents include ion-exchange, chemical precipitation, electro dialysis, electrolytic extraction, reverse

*Corresponding author. E-mail: alemayehuabebaw@yahoo.com 
osmosis and cementation. These methods are expensive and have the inability to remove metals at low concentration. Compared to the aforementioned techniques, adsorption has shown to be a more economically favorable alternative for the removal of metals from aqueous solutions. Activated carbon is the most widely used adsorbent, but due to its relatively high cost, cost effective adsorbents for treatment of metal contaminated wastewaters are necessary particularly in developing countries [6-8].

This research focuses on the adsorption behavior of different parts of $M$. stenopetala for the removal of $\mathrm{Ni}$ (II) present in industrial effluent. Literature review shows that no work has been reported for removal of $\mathrm{Ni}(\mathrm{II})$ using $M$. stenopetala as an adsorbent from industrial effluents in Ethiopia. Therefore a work on adsorption mechanism and optimum condition determination is initiated.

\section{EXPERIMENTAL}

\section{Preparation of adsorbents}

The samples of $M$. stenopetala (leaves, barks and seeds) were collected from kola share village, near Arbaminch which is about $500 \mathrm{~km}$ from Addis Ababa, Ethiopia after authenticated by an expert. These samples were sealed in cleaned polyethylene plastic containers preserved inside of an ice bag and transported to the laboratory. The fresh leaves and barks were cleaned with distilled water separately to remove any contaminants. The cleaned leaves were dried for a period of three days at room temperature $\left(23 \pm 2{ }^{\circ} \mathrm{C}\right)$. The cleaned barks were chopped with table knife into small pieces and then dried at $105{ }^{\circ} \mathrm{C}$ over night in a thermostatically controlled oven to attain constant weight. Seeds were deshelled by hand and cleaned with distilled water. The cleaned seeds were chopped into small pieces and then dried for $24 \mathrm{~h}$ at $110^{\circ} \mathrm{C}$ in oven. All these dried adsorbents were ground by mortar and pestle into fine powder, sieved by 0.25 to 0.5 $\mathrm{mm}$ sieve in order to get particle size of less than $0.5 \mathrm{~mm}[9,10]$.

\section{Preparation of metal ion solutions}

The stock solutions of $\mathrm{Ni}$ (II) having concentration $1,000 \mathrm{mg} / \mathrm{L}$ was prepared by dissolving the analytical grade of $\mathrm{Ni}\left(\mathrm{NO}_{3}\right)_{2} \cdot 6 \mathrm{H}_{2} \mathrm{O}(99 \%)$ with distilled water. The other working solutions were prepared by diluting the stock standard solution with distilled water.

\section{Batch mode adsorption studies}

Adsorption experiments were conducted for nickel ion by varying metal ion concentration (5-50 $\mathrm{mg} / \mathrm{L}$ ), adsorbent dose (0.5-3.0 g), contact time (30-240 $\mathrm{min})$, agitation speed (100-350 rpm), temperature $\left(23-60{ }^{\circ} \mathrm{C}\right)$ and $\mathrm{pH}(2-8)$ until optimum conditions of adsorption was obtained for $\mathrm{Ni}(\mathrm{II})$ in each adsorbents. In these optimization procedures one parameter was varied while the others were kept constant. The $\mathrm{pH}$ of each solution was adjusted to the desired value by adding $0.1 \mathrm{M} \mathrm{NaOH}$ (BDH, England or 0.1 M HCl (NICE Chemicals, India). Agitation of the samples were carried out in Gemmy orbit (model: VRN-480) and water bath shakers using $250 \mathrm{~mL}$ Erlenmeyer flasks and the total volume of the reaction mixture was kept at $50 \mathrm{~mL}[10,11]$.

The mixtures were filtered through Whatman No. 42 filter paper. The filtrates were analyzed by the flame atomic absorption spectrometry (ELICO SL 194, India). The concentration of nickel was measured at $232.0 \mathrm{~nm}$ wavelength, $2.5 \mathrm{~nm}$ slit width and $12 \mathrm{~mA}$ current. The FAAS was adjusted to measure each sample five times and the results taken as an avage. 


\section{Determination of adsorption models}

After identifying the optimum conditions of adsorption parameters, kinetic, isotherm and thermodynamic studies were carried out to distinguish the adsorption mechanism occurred through the adsorption process. The adsorption kinetic studies were carried out by varying contact time around the optimum condition obtained from the optimization procedure and keeping the other parameters at optimum. The experimental contact time variation data were carried out for nickel at $20 \mathrm{mg} / \mathrm{L}$ concentration, $2 \mathrm{~g}$ of bark, $250 \mathrm{rpm}$ agitation speed, $30{ }^{\circ} \mathrm{C}$ and $\mathrm{pH}$ of 6 for bark adsorbent and at $50 \mathrm{mg} / \mathrm{L}$ concentration, $2.5 \mathrm{~g}$ of seed, $300 \mathrm{rpm}$ agitation speed, $23{ }^{\circ} \mathrm{C}$ and $\mathrm{pH}$ of 6 for seed adsorbent. Each of the five prepared solutions was repeated three times in the batch adsorption procedure. The adsorption isotherm studies were carried out using the temperature variation, using contact time variation and also by varying the adsorbate concentrations around the optimum condition obtained in the optimization procedure as follow. The experimental adsorbate concentration variations were carried out for $\mathrm{Ni}$ (II) at $2 \mathrm{~g}$ of bark, $250 \mathrm{rpm}$ agitation speed, $120 \mathrm{~min}$. contact time, $30{ }^{\circ} \mathrm{C}$ and $\mathrm{pH}$ of 6 upon studying using bark adsorbent and at $2.5 \mathrm{~g}$ of seed, $300 \mathrm{rpm}$ agitation speed, 90 min contact time, $23^{\circ} \mathrm{C}$ and $\mathrm{pH}$ of 6 for seed adsorbent. Each of the five prepared solutions was repeated three times in the batch adsorption procedure. Adsorption thermodynamic studies were also carried out using the temperature variation.

\section{Studies on industrial wastewater}

Industrial wastewater was collected at the point of discharge from Modjo Tannery Share Company which is about $80 \mathrm{~km}$ from Addis Ababa. Wastewater sample was collected in polyethylene plastic containers previously cleaned by washing in non-ionic detergent, rinsed with tap water and later soaked in $10 \% \mathrm{HNO}_{3}$ for $24 \mathrm{~h}$ and finally rinsed with distilled water prior to usage. Composite sampling method (at different distance of discharge channels and at different time intervals) was used in collecting the wastewater samples. These samples were transported to the laboratory, stored in the refrigerator at about $4{ }^{\circ} \mathrm{C}$ to lower vapor pressure. For preventing chemical reactions (for example, metal ions may oxidize to form insoluble oxides or hydroxides), the samples were acidified with $\mathrm{HNO}_{3}$ to a $\mathrm{pH}$ below two, as most nitrates are soluble, and excess nitrate prevents precipitation [12,13]. Keeping the optimum conditions of adsorption in synthetic wastewater, adsorption studies were carried out in real wastewater sample.

\section{RESULTS AND DISCUSSION}

\section{Effect of initial metal ion concentration on adsorption}

The effect of initial concentrations of nickel on adsorption was studied by varying the adsorbates concentration from $5-50 \mathrm{mg} / \mathrm{L}$ with respect to leaf, bark and seed adsorbents by holding the other parameters constant. The results are presented in Figure 1.

The percent removal of nickel ion by the adsorbents initially increase with increasing nickel ion concentration and a maximum value reached at concentrations of 30,20 and $50 \mathrm{mg} / \mathrm{L}$ for leaf, bark and seed adsorbents respectively. Hence these concentrations were used to further study other parameters. The initial rapid increase in percent removal of metal ions can be attributed to the interactions between the metal ions and the active sites of the adsorbent. This may be due to the higher adsorption rate and the utilization of all the active sites available for adsorption at higher concentrations. However further increase in initial concentration of adsorbates cause to decrease the percent removal. This can be explained based on the fact that 
all the adsorbents had limited number of active sites, which would have become saturated above a certain metal ion concentration.

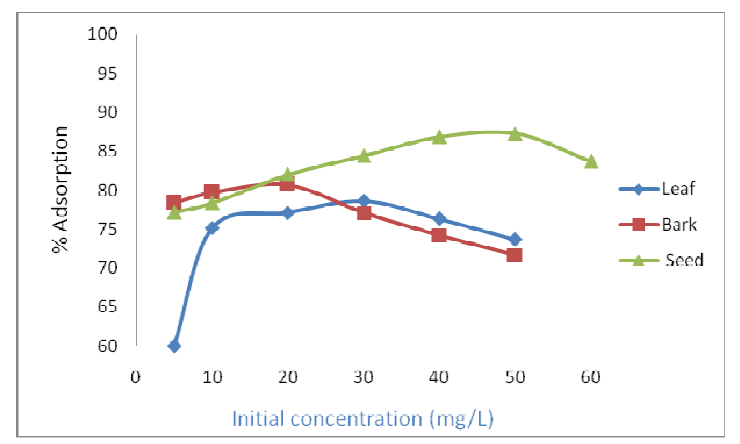

Figure 1.Effect of initial concentration on Ni(II) removal (1 g adsorbent, $250 \mathrm{rpm}$ agitation speed, $\mathrm{pH}$ of 2.5, 60 min contact time and room temperature for each adsorbent).

\section{Effect of adsorbent dose}

The effect of adsorbent doses on adsorption of nickel was studied in the range of 0.5-3.0 $\mathrm{g}$ for leaf, bark and seed adsorbents. The results are given in Figure 2.

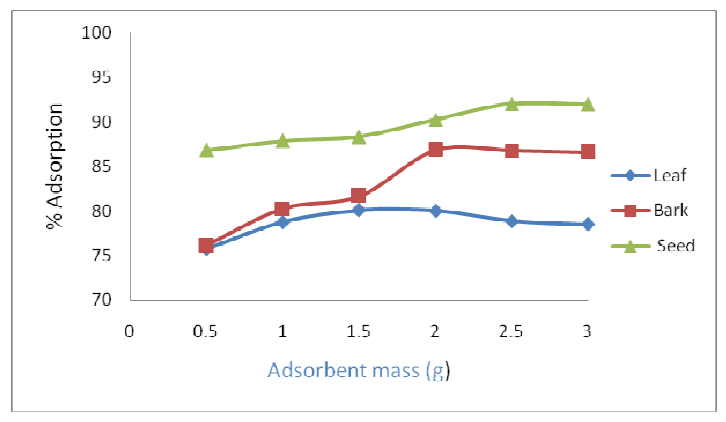

Figure 2. Effect of adsorbent dose on $\mathrm{Ni}$ (II) removal (room temperature, $\mathrm{pH}$ of 2.5, $250 \mathrm{rpm}$ agitation speed and 60 min contact time for each adsorbent and also concentrations of 30,20 and $50 \mathrm{mg} / \mathrm{L}$ for leaf, bark and seed respectively).

The optimum adsorbent masses for $\mathrm{Ni}$ (II) obtained were 1.5, 2.0 and $2.5 \mathrm{~g}$ of leaf, bark and seed, respectively. The increase in the adsorption percentage with rise in adsorbent dosage may be due to increase the available adsorption active sites on the adsorbents and thus making easier penetration of the metal ion to the sorption sites. However, any further addition of the adsorbent beyond the obtained optimum masses did not cause any significant change in the adsorption. This may be due to overlapping of adsorption sites as a result of overcrowding of adsorbent particles and also due to decrease in the contact time required to reach apparent equilibrium as the adsorbent dose increase. 


\section{Effect of agitation speed}

The effect of agitation speeds on adsorption for Ni(II) was studied in the range of 100-350 rpm for each adsorbent. The results are presented in Figure 3. From the results presented in Figure 3, the maximum adsorption of $\mathrm{Ni}(\mathrm{II})$ occurred at 250, 250 and $300 \mathrm{rpm}$ for leaf, bark and seed adsorbents, respectively. At low agitation speed, the adsorbent do not spread in the sample but accumulated. This will bury the active sites of the lower layer adsorbent and only the upper layer adsorbent active sites adsorb the metal ion. This indicates that agitation rate should be sufficient to assure that all the surface binding sites are readily available for metal uptake. But for further increase in agitation speed, percentage removal decrease. This may be attributed to an increase desorption tendency of adsorbate molecules.

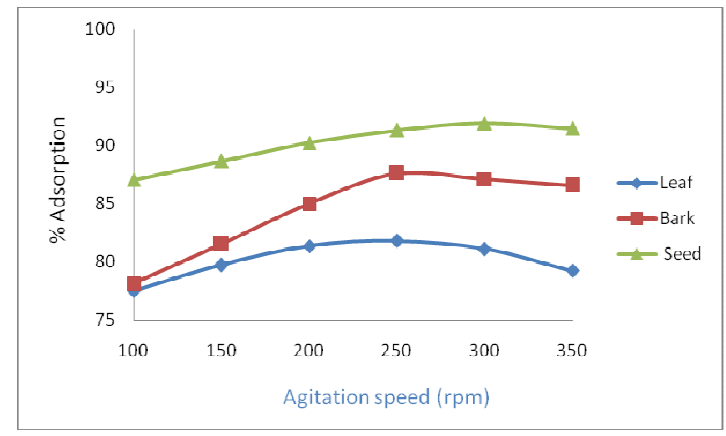

Figure 3. Effect of agitation speed for $\mathrm{Ni}(\mathrm{II})$ removal (room temperature, $30 \mathrm{mg} / \mathrm{L}, \mathrm{pH}$ of 2.5 , $1.5 \mathrm{~g}$ leaf and $60 \mathrm{~min}$ time for leaf, at room temperature, $20 \mathrm{mg} / \mathrm{L}, \mathrm{pH}$ of $2.5,2 \mathrm{~g}$ bark and $60 \mathrm{~min}$ time for bark and also at room temperature, $50 \mathrm{mg} / \mathrm{L}, \mathrm{pH}$ of 2.5, $2.5 \mathrm{~g}$ seed and $60 \mathrm{~min}$. time for seed).

\section{Effect of contact time}

The effect of contact times on adsorption for nickel was studied at 30, 60, 90, 120, 150 and 240 min with respect to leaf, bark and seed adsorbents. The results are presented in Figure 4.

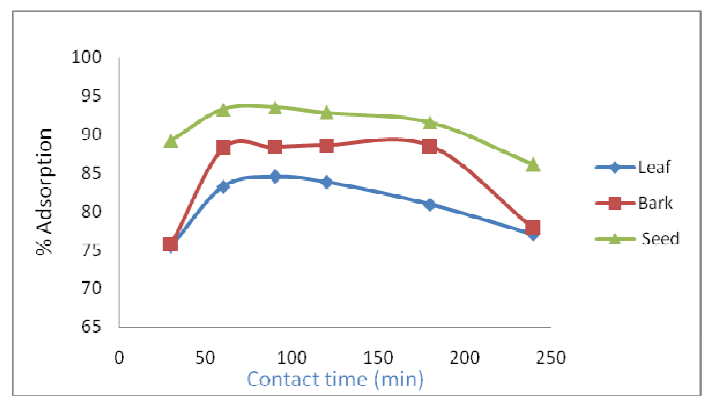

Figure 4. Effect of contact time for Ni(II) removal $(30 \mathrm{mg} / \mathrm{L}, 1.5 \mathrm{~g}$ leaf, $\mathrm{pH}$ of 2.5, $250 \mathrm{rpm}$ agitation speed and room temperature for leaf, at $20 \mathrm{mg} / \mathrm{L}, 2 \mathrm{~g}$ bark, $\mathrm{pH}$ of $2.5,250$ $\mathrm{rpm}$ agitation speed and room temperature for bark and also at $50 \mathrm{mg} / \mathrm{L}, 2.5 \mathrm{~g}$ seed, $\mathrm{pH}$ of 2.5, $300 \mathrm{rpm}$ agitation speed and room temperature for seed). 
From the results presented in Figure 4, the rate of percent removal is higher at the beginning because of large number of vacant surface sites available for adsorption. The maximum adsorption of $\mathrm{Ni}$ (II) was obtained at contact times of 90, 120 and 90 min for leaf, bark and seed adsorbents, respectively. After these equilibrium contact time, a decrease in the amount adsorbed was observed. Therefore, in a mixture of the adsorbents and metal ion, the metal ion competes for the adsorption sites on the adsorbent. This competition could affect the diffusion properties of the metal ions and also the adsorption capacity of the metal ions.

\section{Effect of $p H$}

The effect of $\mathrm{pH}$ on adsorption for $\mathrm{Ni}(\mathrm{II})$ was studied in the range of $\mathrm{pH}$ 2-8 with respect to leaf, bark and seed adsorbents. The results are presented in Figure 5. In the present investigation maximum adsorption of nickel ion was obtained at $\mathrm{pH}$ of 5, 6 and 6 for leaf, bark and seed adsorbents, respectively. The increase in percentage removal of metal ion due to increase in $\mathrm{pH}$ may be explained on the basis of a decrease in competition between proton $\left(\mathrm{H}^{+}\right)$and positively charged metal ion at the surface sites and also by decrease in positive charge near the surface resulting in a lower repulsion of the adsorbing metal ion and more negative groups for complexation of metal cations are provided. When alkalinity increased from $\mathrm{pH}$ value of 7 to 8 , there was a further decrease in the rate of adsorption by the adsorbent for metal ions in the aqueous solution. At higher $\mathrm{pH}$ values, metal ions tend to hydrolyze and precipitate instead of adsorption and the adsorbent deteriorated with accumulation of metal ions, making true adsorption studies impossible.

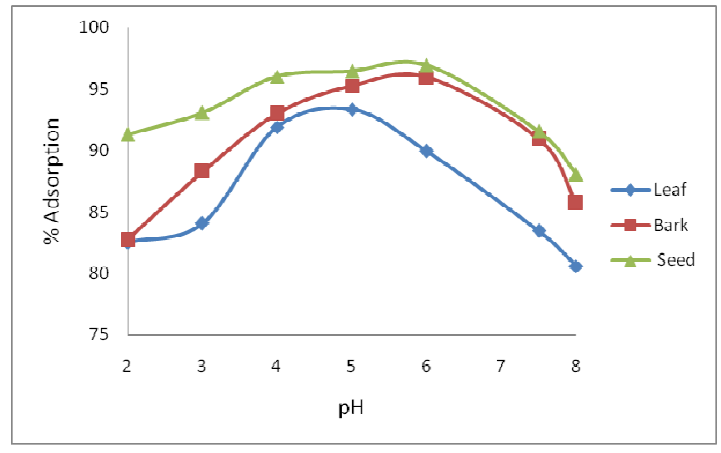

Figure 5. Effect of $\mathrm{pH}$ on $\mathrm{Ni}(\mathrm{II})$ removal $(30 \mathrm{mg} / \mathrm{L}, 1.5 \mathrm{~g}$ leaf, $250 \mathrm{rpm}$ agitation speed, $90 \mathrm{~min}$. time and room temperature for leaf, at $20 \mathrm{mg} / \mathrm{L}, 2 \mathrm{~g}$ bark, $250 \mathrm{rpm}$ agitation speed, 120 min. time and room temperature for bark and also at $50 \mathrm{mg} / \mathrm{L}, 2.5 \mathrm{~g}$ seed, $300 \mathrm{rpm}$ agitation speed, $90 \mathrm{~min}$. time and room temperature for seed adsorbent).

\section{Effect of temperature}

The effect of temperature on adsorption for Ni(II) was studied at $23,30,40,50$ and $60{ }^{\circ} \mathrm{C}$ with respect to leaf, bark and seed adsorbents. The results are presented in Figure 6. In the reported study, a slight increase in percent removal with increased temperature for the adsorbents was observed. The maximum adsorption of nickel ion was obtained at temperature of 40, 30 and 23 ${ }^{\circ} \mathrm{C}$ for leaf, bark and seed adsorbents, respectively. As the temperature increases the kinetic energy of metal ions in solution also increase to make the number of metal ions reaching to the adsorbent surface maximum. The observed decrease in Ni(II) percentage removal with 
increasing temperature suggests weak binding interaction between the active sites and the metal ions, which supports physisorption. Furthermore, physical adsorption reactions are normally exothermic; hence the extent of adsorption generally increases with a decrease in temperature. At optimum experimental conditions the percent adsorption of synthetic wastewater sample was found to be 93.90, 96.25 and 97.50 for leaf, bark and seed, respectively.

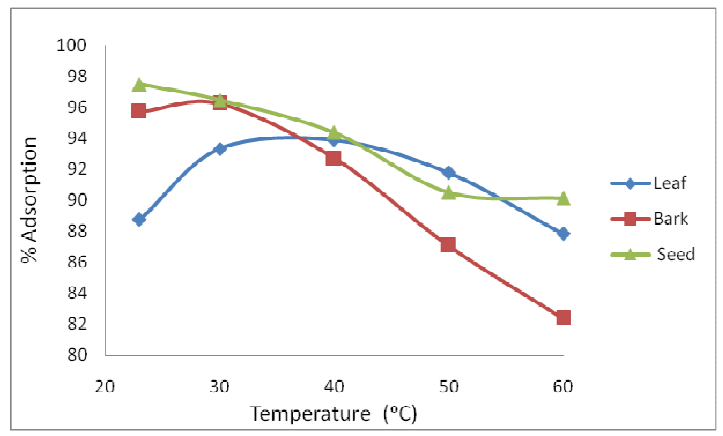

Figure 6. Effect of temperature on $\mathrm{Ni}(\mathrm{II})$ removal $(30 \mathrm{mg} / \mathrm{L}, 1.5 \mathrm{~g}$ leaf, $250 \mathrm{rpm}$ agitation speed, $90 \mathrm{~min}$ time and $\mathrm{pH}$ of 5 for leaf, at $20 \mathrm{mg} / \mathrm{L}, 2 \mathrm{~g}$ bark, $250 \mathrm{rpm}$ agitation speed, 120 min time and $\mathrm{pH}$ of 6 for bark and also at $50 \mathrm{mg} / \mathrm{L}, 2.5 \mathrm{~g}$ seed, $300 \mathrm{rpm}$ agitation speed, 90 min time and $\mathrm{pH}$ of 6 for seed).

In summary, adsorption efficiency of the adsorbents in the optimization process were observed in the order of seed > bark > leaf. Even though the adsorption efficiency of leaf is also good for further study, it was observed that the water after adsorption process by leaf was so colorful and had bad odor that makes another waste for the environment. Therefore more studies regarding adsorption models and industrial wastewater were made for bark and seed adsorbents of M. stenopetala.

\section{Investigation of adsorption kinetics}

Adsorption kinetic study for nickel was studied by varying contact time around the optimum conditions obtained in the optimization adsorption procedures for bark and seed of $M$. stenopetala adsorbents and keeping the other parameters on their optimum conditions.

The kinetic models used in this study are explained as follow:

Pseudo-first-order model. $\log \left(q_{e}-q\right)=\log q_{e}-\frac{k_{f}}{2.303} t$

and: $q=\frac{\left(C_{o}-C_{e}\right) V}{m}$

where $\mathrm{C}_{\mathrm{o}}$ and $\mathrm{C}_{\mathrm{e}}$ are the initial and equilibrium adsorbate concentrations in solution $(\mathrm{mg} / \mathrm{L})$ respectively, $\mathrm{V}$ is volume of solution $(\mathrm{L})$ and $m$ is mass of dry adsorbent $(\mathrm{g}), q_{e}$ is the maximum adsorption amount of adsorbent in equilibrium at optimum condition $(\mathrm{mg} / \mathrm{g}), \mathrm{k}_{\mathrm{f}}$ is rate constant of pseudo-first-order model (1/min) and $\mathrm{t}$ is the time [2, 5, 14].

Pseudo-second-order model. $\frac{t}{q}=\frac{1}{k_{s} q_{e}^{2}}+\frac{1}{q_{e}} t$ 
where $k_{\mathrm{s}}$ is rate constant of pseudo-second-order model $(\mathrm{g} / \mathrm{mg} \mathrm{min})$. Initial sorption rate in $\mathrm{mg} / \mathrm{gmin}$, as $t \rightarrow 0$ can be defined as: $\left(\frac{d q}{d t}\right)_{\text {initial }}=k_{s} q_{e}^{2}$

The initial sorption rate, the equilibrium adsorption capacity $\left(q_{e}\right)$, and the pseudo-second-order rate constant $k_{s}$ can be determined from plot of $t / q$ versus $t[2,14]$.

Elovich model. $q_{t}=\frac{\operatorname{In}(\alpha \beta)}{\beta}+\frac{\operatorname{Int}}{\beta}$

where, $\alpha$ is the initial adsorption rate $(\mathrm{mg} / \mathrm{g} \min ), \beta$ is related to the extent of surface coverage and the activation energy for chemisorption $(\mathrm{g} / \mathrm{mg})$. A plot of $\mathrm{q}_{\mathrm{t}}$ versus lnt gives a linear trace with a slope of $(1 / \beta)$ and an intercept of $1 / \beta \ln (\alpha \beta)$ [15-17].

Intraparticle diffusion model. $\ln q=\ln K_{i d}+a \ln t$

where $\mathrm{t}$ is the contact time, in min, $a$ is a dimensionless constant and $\mathrm{K}_{\mathrm{id}}$ is the intraparticle diffusion rate constant, in $\min ^{-1}$. According to this model, the plot of "Inq" versus "Int" should be linear if intraparticle diffusion is involved in the adsorption process [18]. The results of kinetic parameters determined using contact time variation of $\mathrm{Ni}(\mathrm{II})$ are given in Table 1.

From Table 1 , the $R^{2}$ values suggest that the pseudo-second order $\left(R^{2} \geq 0.98\right)$ and pseudo first order $\left(\mathrm{R}^{2} \geq 0.87\right)$ model kinetics provide a good model for the adsorption of nickel ion on bark and seed of $M$. stenopetala adsorbents. The experimental $\mathrm{q}_{\mathrm{e}}$ values were closer to the calculated $\mathrm{q}_{\mathrm{e}}$ values obtained from the second order kinetic plots compared to those of the first order kinetic plots which indicate better applicability of pseudo-second order than pseudo first order model kinetics. These suggest that the adsorption data are well represented by pseudosecond order kinetics and supports the assumption that the rate limiting step of metal adsorption on the adsorbents may be chemical sorption or chemisorption [2, 3].

Table 1. Kinetic parameters determined using contact time variation of $\mathrm{Ni}(\mathrm{II})$.

\begin{tabular}{|c|c|c|c|}
\hline Kinetic models & Parameters & Bark & Seed \\
\hline Pseudo-first-order & $\mathrm{k}_{\mathrm{f}}(1 / \mathrm{min})$ & 0.047 & 0.038 \\
& $\mathrm{q}_{\mathrm{cal}}(\mathrm{mg} / \mathrm{g})$ & 2.828 & 0.0033 \\
& $\mathrm{R}^{2}$ & 0.9664 & 0.9228 \\
\hline Pseudo-second-order & $\mathrm{K}_{\mathrm{s}}(\mathrm{g} / \mathrm{mg} \cdot \mathrm{min})$. & 0.075 & 0.087 \\
& $\mathrm{q}_{\mathrm{e}}(\mathrm{mg} / \mathrm{g})$ & 0.560 & 0.753 \\
& $\mathrm{R}^{2}$ & 0.9952 & 0.9837 \\
\hline Elovich model & $\alpha(\mathrm{mg} / \mathrm{g} \min )$. & 0.191 & $5.44 \times 10^{-6}$ \\
& $\beta(\mathrm{g} / \mathrm{mg})$ & 12.034 & 6.313 \\
& $\mathrm{R}^{2}$ & 0.8922 & 0.6202 \\
\hline Intraparticle diffusion & $\mathrm{k}_{\mathrm{id}}\left(\mathrm{min}^{-\mathrm{a}}\right)$ & 0.1966 & 2.01536 \\
& $\mathrm{a}$ & 0.1806 & 0.17576 \\
& $\mathrm{R}^{2}$ & 0.8899 & 0.6254 \\
\hline
\end{tabular}

Investigation of adsorption isotherms

In this study, adsorption isotherm models were evaluated using three parameters such as temperature variation, contact time variation and also using adsorbate concentration variation. The adsorption isotherm models used for this study are given as follow: 
Langmuir isotherm. $\frac{C_{e}}{q}=\frac{C_{e}}{Q}+\frac{1}{b Q}$

"Q" and " $b$ " in this case can be determined from the plot of $\mathrm{C}_{\mathrm{e}} / \mathrm{q}$ versus $\mathrm{C}_{\mathrm{e}}$. "Q" indicates the maximum sorption up on complete monolayer saturation. Higher value of " $b$ " indicates the adsorbent has high affinity for the adsorbate and vice versa. The essential characteristics of the Langmuir isotherm can be expressed by: $R_{L}=\frac{1}{\left(1+b C_{o}\right)}$

where $C_{o}(m g / L)$ is the initial concentration of adsorbate, and b $(\mathrm{L} / \mathrm{mg})$ is Langmuir constant. The value of $R_{L}$ indicates the shape of the isotherm which is unfavorable $\left(R_{L}>1\right)$, linear $\left(R_{L}=\right.$ $1)$, favorable $\left(0<R_{L}<1\right)$, or irreversible $\left(R_{L}=0\right)[2,19]$.

Freundlich isotherm. $q=K_{F} C_{e}^{1 / n}$ Or $\log \mathrm{q}=\log \mathrm{K}_{\mathrm{F}}+\frac{1}{n} \log \mathrm{C}_{\mathrm{e}}$

where " $\mathrm{n}$ " is heterogeneity factor representing the deviation from linearity of adsorption, " $\mathrm{K}_{\mathrm{F}}$ " indicates the adsorption capacity of adsorbent related to the bonding energy, $\mathrm{mg} / \mathrm{g}(\mathrm{L} / \mathrm{mg})^{1 / \mathrm{n}}$. For $1 / \mathrm{n}$ less than unity, adsorption is the predominant process take place otherwise desorption becomes predominant $[14,19]$.

Tempkin isotherm. $q=B_{1} \operatorname{In} K_{T}+B_{1} \operatorname{In} C_{e}$

where $\mathrm{B}_{1}=\frac{R T}{b_{T}}$

Regression of $q$ versus lnCe enables the determination of isotherm constants $K_{\mathrm{T}}$ and $B_{1} . K_{\mathrm{T}}$ is equilibrium binding constant $(\mathrm{L} / \mathrm{g})$ corresponding to maximum binding energy and constant $B_{1}$ is related to the heat of adsorption, $\mathrm{R}$ the gas constant $(8.314 \mathrm{~J} / \mathrm{mol} \mathrm{K}), \mathrm{b}_{\mathrm{T}}$ is Temkin isotherm constant that indicate adsorption potential of adsorbent and $\mathrm{T}$ is the absolute temperature $(\mathrm{K})$ $[2,5,15-17]$.

Dubinin-Radushkevich $(D-R)$ Isotherm. $\operatorname{Inq}=\operatorname{In} Q_{m}-K \varepsilon^{2}$

where $K$ is a constant related to the adsorption energy, $Q_{\mathrm{m}}$ the theoretical saturation capacity, $\mathcal{E}$ the Polanyi potential can be calculated by: $\varepsilon=R \operatorname{In}\left(1+\frac{1}{C_{e}}\right)$

The plot of Inq versus $\varepsilon^{2}$ gives slope, $K\left(\mathrm{~mol}^{2} / \mathrm{J}^{2}\right)$ and the intercept yields the adsorption capacity, $Q_{m}\left(\mathrm{mg} \mathrm{g}^{-1}\right)$. The mean free energy of adsorption $(E)$ can be expressed by: $E=\frac{1}{\sqrt{2 K}}$ It has been reported that physiosorption processes usually have adsorption energies $<40 \mathrm{~kJ} / \mathrm{mol}$ and above this value sorption is of chemisorption mechanism. If the mean adsorption energy value is between 8 and $16 \mathrm{~kJ} / \mathrm{mol}$, the adsorption process follows chemical ion exchange and if "E" $<8 \mathrm{~kJ} / \mathrm{mol}$ the sorption process is physical in nature $[9,20]$.

The results of isotherm parameters determined using concentration variation, temperature variation and contact time variation for nickel ion are given in Table 2, 3 and 4, respectively. From the isotherm parameter results (Table 2, 3 and 4), the Langmuir model yielded the best fit with $\mathrm{R}^{2}$ value higher as compared to the other three models. The $\mathrm{R}^{2}$ value is greater than 0.895 in Table 2 and also $\mathrm{R}^{2}$ value is greater than 0.998 in both Table 3 and 4 using both adsorbents. The value of dimensionless constant separation factor $\left(R_{L}\right)$ was obtained between 0 and 1 on the three parameters under study using both bark and seed adsorbents, this implies the adsorbate is favorably adsorbed by the adsorbents. 
Table 2. Isotherm parameters determined using concentration variation of $\mathrm{Ni}(\mathrm{II})$.

\begin{tabular}{|c|c|c|c|}
\hline & Parameters & Bark & Seed \\
\hline Isotherm Models & $\mathrm{Q}(\mathrm{mg} / \mathrm{g})$ & 0.9960 & 1.2834 \\
& $\mathrm{~b}(\mathrm{~L} / \mathrm{mg})$ & 0.6903 & 1.6519 \\
& $\mathrm{R}_{\mathrm{L}}$ & $0.046-0.127$ & $0.010-0.015$ \\
& $\mathrm{R}^{2}$ & 0.9359 & 0.9806 \\
\hline Freundlich isotherm & $\mathrm{K}_{\mathrm{F}, \mathrm{mg} / \mathrm{g}(\mathrm{L} / \mathrm{mg})^{1 / \mathrm{n}}}$ & 0.3750 & 0.833 \\
& $\mathrm{n}$ & 2.0325 & 4.6860 \\
& $\mathrm{R}^{2}$ & 0.8052 & 0.6678 \\
\hline Temkin isotherm & $\mathrm{b}_{\mathrm{T}}$ & 1184.38 & 11929.8 \\
& $\mathrm{~K}_{\mathrm{T}} \times 10^{-6}(\mathrm{~L} / \mathrm{g})$ & 6.5715 & 56.0454 \\
& $\mathrm{R}^{2}$ & 0.8954 & 0.7147 \\
\hline Dubinin-Radushkevich isotherm & $\mathrm{Q}_{\mathrm{m}}(\mathrm{mg} / \mathrm{g})$ & 0.7114 & 1.123 \\
& $\mathrm{~K} \times 10^{-8}\left(\mathrm{~mol}{ }^{2} / \mathrm{J}^{2}\right)$ & 17.1630 & 11.64 \\
& $\mathrm{E}(\mathrm{kJ} / \mathrm{mol})$ & 1.705 & 2.076 \\
\hline
\end{tabular}

Table 3. Isotherm parameters determined using temperature variation of $\mathrm{Ni}$ (II).

\begin{tabular}{|c|c|c|c|}
\hline Isotherm Models & Parameters & Bark & Seed \\
\hline Langmuir isotherm & $\mathrm{Q}(\mathrm{mg} / \mathrm{g})$ & 0.399 & 0.441 \\
& $\mathrm{~b}(\mathrm{~L} / \mathrm{mg})$ & 6.180 & 15.75 \\
& $\mathrm{R}_{\mathrm{L}}$ & 0.0082 & 0.0013 \\
& $\mathrm{R}^{2}$ & 0.9985 & 0.9998 \\
\hline Freundlich isotherm & $\mathrm{K}_{\mathrm{F}} \mathrm{mg} / \mathrm{g}(\mathrm{L} / \mathrm{mg})^{1 / \mathrm{n}}$ & 0.4726 & 0.4730 \\
& $\mathrm{n}$ & 10.31 & 16.98 \\
& $\mathrm{R}^{2}$ & 0.9591 & 0.9806 \\
\hline Temkin isotherm & $\mathrm{b}_{\mathrm{T}}$ & 0.044 & 0.028 \\
& $\mathrm{~K}_{\mathrm{T}} \times 10^{-6}(\mathrm{~L} / \mathrm{g})$ & $1.9 \times 10^{-5}$ & $3.82 \times 10^{-8}$ \\
& $\mathrm{R}^{2}$ & 0.9662 & 0.9825 \\
\hline Dubinin-Radushkevich & $\mathrm{Q}_{\mathrm{m}}(\mathrm{mg} / \mathrm{g})$ & 0.423 & 0.455 \\
isotherm & $\mathrm{K} \times 10^{-8}\left(\mathrm{~mol}{ }^{2} / \mathrm{J}^{2}\right)$ & 261.82 & 98.73 \\
& $\mathrm{E}\left(\mathrm{kJ}^{2} / \mathrm{mol}\right)$ & 0.044 & 0.071 \\
& $\mathrm{R}^{2}$ & 0.8152 & 0.8798 \\
\hline
\end{tabular}

Table 4. Isotherm parameters determined using contact time variation of $\mathrm{Ni}(\mathrm{II})$.

\begin{tabular}{|c|c|c|c|}
\hline Isotherm Models & Parameters & Bark & Seed \\
\hline Langmuir isotherm & $\mathrm{Q}(\mathrm{mg} / \mathrm{g})$ & 0.423 & 0.82 \\
& $\mathrm{~b}(\mathrm{~L} / \mathrm{mg})$ & 9.48 & 3.23 \\
& $\mathrm{R}_{\mathrm{L}}$ & 0.0053 & 0.006 \\
& $\mathrm{R}^{2}$ & 0.9995 & 0.9991 \\
\hline Freundlich isotherm & $\mathrm{K}_{\mathrm{F}} \mathrm{mg} / \mathrm{g}(\mathrm{L} / \mathrm{mg})^{1 / \mathrm{n}}$ & 0.473 & 1.02 \\
& $\mathrm{n}$ & 12.87 & 0.9667 \\
\hline Temkin isotherm & $\mathrm{R}^{2}$ & 0.9771 & 31568 \\
& $\mathrm{~b}_{\mathrm{T}}$ & 70400 & 2.29 \\
& $\mathrm{~K}_{\mathrm{T}} \times 10^{-6}(\mathrm{~L} / \mathrm{g})$ & 1.808 & 0.9714 \\
\hline Dubinin-Radushkevich isotherm & $\mathrm{R}^{2}$ & 0.9804 & 1.156 \\
& $\mathrm{Q}_{\mathrm{m}}(\mathrm{mg} / \mathrm{g})$ & 0.4379 & 9.00 \\
& $\mathrm{~K} \times 10^{-8}\left(\mathrm{~mol}{ }^{2} / \mathrm{J}^{2}\right)$ & 2.32 & 2.38 \\
\hline
\end{tabular}

Bull. Chem. Soc. Ethiop. 2013, 27(1) 
The confirmation of the experimental data into Langmuir isotherm equation may be due to formation of monolayer adsorption on a uniform surface with a finite number of adsorption sites $[9,21,22]$. The applicability of the four isotherm models in Table 3 and 4 were consistently obtained within the decreasing order of: Langmuir $>$ Temkin $>$ Freundlich $>$ DubininRadushkevich isotherm model using bark and seed adsorbents.

\section{Study on adsorption thermodynamics}

In this study, the values of $\Delta \mathrm{G}^{\circ}, \Delta \mathrm{H}^{\circ}$ and $\Delta S^{\circ}$ were determined from classical Van't Hoff equation [23]:

$\Delta G^{0}=-R T \operatorname{In} K_{c} \quad$ and $\Delta G^{0}=\Delta H^{0}-T \Delta S^{0}$

$\operatorname{In} K_{c}=\frac{\Delta S^{0}}{R}-\frac{\Delta H^{0}}{R T}$

where $R$ is universal gas constant $(8.314 \mathrm{~J} / \mathrm{mol} \mathrm{K}), \mathrm{T}(\mathrm{K})$ is the absolute temperature and $\mathrm{K}_{\mathrm{c}}$ is the single point or linear sorption distribution coefficient defined as: $\mathrm{K}_{\mathrm{c}}=\mathrm{C}_{\mathrm{o}} / \mathrm{C}_{\mathrm{e}}$ in which $\mathrm{C}_{\mathrm{o}}$ and $C_{e}$ are the initial adsorbate concentrations added to the solid phase adsorbent and equilibrium adsorbate concentrations remained in the liquid phase $(\mathrm{mg} / \mathrm{L})$, respectively. The results for adsorption thermodynamic parameters of $\mathrm{Ni}(\mathrm{II})$ are given in Table 5.

From the results given in Table 5 , the values of $\Delta G^{0}$ calculated are negative for the adsorption of metal ion onto the adsorbents at all temperatures which confirms the feasibility of the process and the spontaneous nature of the adsorption. The obtained $\Delta \mathrm{G}^{\circ}$ value of nickel was less than $-10 \mathrm{~kJ} / \mathrm{mol}$ which indicate physical adsorption as the predominant mechanism in the sorption process. The values of $\Delta \mathrm{H}^{0}$ obtained for $\mathrm{Ni}(\mathrm{II})$ was within the range of -22.981 to $41.936 \mathrm{~kJ} / \mathrm{mol}$ using bark and seed adsorbents under the studied temperature range. A negative value of $\Delta \mathrm{H}^{0}$ implies that the adsorption phenomenon is exothermic and its magnitude less than $42 \mathrm{~kJ} / \mathrm{mol}$ implies formation of physical adsorption. A negative value of $\Delta \mathrm{S}^{0}$ suggests that the adsorption process involves an associative mechanism rather than dissociative. Adsorption leads to order through the formation of an activated complex between adsorbate and adsorbent. Also negative value of $\Delta S^{0}$ reflects that no significant change occur in the internal structures of the adsorbent during the adsorption process.

Table 5. Adsorption thermodynamic parameters of Ni(II).

\begin{tabular}{|l|c|c|c|c|c|c|}
\hline Thermodynamic & Adsorbents & \multicolumn{5}{|c|}{ Temperature (K) } \\
\cline { 3 - 7 } Parameter & & 296.15 & 303.15 & 313.15 & 323.15 & 333.15 \\
\hline$\Delta \mathrm{G}^{\circ}(\mathrm{kJ} / \mathrm{mol})$ & Bark & -8.263 & -7.612 & -6.684 & -5.755 & -4.826 \\
& Seed & -9.172 & -8.569 & -7.709 & -6.848 & -5.988 \\
\hline$\Delta \mathrm{H}^{\circ}(\mathrm{kJ} / \mathrm{mol})$ & Bark & \multicolumn{5}{|c|}{-35.770} \\
& Seed & \multicolumn{5}{|c|}{-92.653} \\
\hline$\Delta S^{\circ}(\mathrm{J} / \mathrm{molK})$ & Bark & \multicolumn{7}{|c|}{-86.042} \\
& Seed & \multicolumn{7}{|c|}{} \\
\hline
\end{tabular}

Application of the developed method in real samples

In order to apply the method on industrial wastewater sample, characterization of the wastewater is important to determine the effect of interfering substances present. Therefore, the levels of some physicochemical characteristics of industrial wastewater samples were studied and the obtained results are given in Table 6. 
Following the optimum conditions of six adsorption parameters obtained in synthetic wastewater, removal of $\mathrm{Ni}$ (II) was studied on the real wastewater. Since the $\mathrm{pH}$ of industrial wastewater sample is 7.8 , the adsorption procedure was also maintained at this $\mathrm{pH}$ for check up and the results are given in Table 7.

The experimental studies showed that the bark and seed of $M$. stenopetala adsorbents could be used as an alternative, inexpensive and effective material to remove toxic $\mathrm{Ni}$ (II) ion from real wastewater. The results obtained are therefore very encouraging for the industrial application of the technique, which brings the concentration of $\mathrm{Ni}(\mathrm{II})$ below the industrial limit in waste water.

Table 6. Some physicochemical characteristics of tannery industrial wastewater.

\begin{tabular}{|l|l|}
\hline Parameters & Values \\
\hline Temperature & $28 \pm 2{ }^{\circ} \mathrm{C}$ \\
\hline $\mathrm{pH}$ & $7.8 \pm 2$ \\
\hline Salinity & 6.4 \\
\hline Conductivity & $10.07 \mathrm{~ms} / \mathrm{cm}$ \\
\hline Total dissolved solid & $8,595 \mathrm{mg} / \mathrm{L}$ \\
\hline Total solids & $12,452 \mathrm{mg} / \mathrm{L}$ \\
\hline Total suspended solids (TSS) & $3,857 \mathrm{mg} / \mathrm{L}$ \\
\hline Alkalinity & $1,320 \mathrm{mg} / \mathrm{L}$ \\
\hline Acidity & $30 \mathrm{mg} / \mathrm{L}$ \\
\hline Dissolved oxygen (DO) & $5.6 \mathrm{mg} / \mathrm{L}$ \\
\hline Chemical oxygen demand (COD) & $292 \mathrm{mg} / \mathrm{L}$ \\
\hline Sulfate & $1,659.85 \mathrm{mg} / \mathrm{L}$ \\
\hline Ni(II) & $5.83 \mathrm{mg} / \mathrm{L}$ \\
\hline
\end{tabular}

Table 7. Adsorption studies on removal of Ni(II) from real wastewater.

\begin{tabular}{|c|c|c|c|c|}
\hline Adsorbent & $\mathrm{pH}$ & $\mathrm{C}_{\mathrm{o}}(\mathrm{mg} / \mathrm{L})$ & $\mathrm{C}_{\mathrm{e}} \pm \mathrm{SD}(\mathrm{mg} / \mathrm{L})$ & \% Adsorption \\
\hline Bark & 6 & 5.83 & $1.01 \pm 0.027$ & 82.68 \\
& 7.8 & 5.83 & $1.12 \pm 0.021$ & 80.79 \\
\hline Seed & 6 & 5.83 & $0.86 \pm 0.032$ & 85.25 \\
& 7.8 & 5.83 & $0.97 \pm 0.024$ & 83.36 \\
\hline
\end{tabular}

where $\mathrm{C}_{\mathrm{o}}$ and $\mathrm{C}_{\mathrm{e}}$ are initial and final adsorbate concentrations in solution respectively.

\section{CONCLUSION}

Optimum conditions of metal ion concentration, adsorbent dose, agitation speed, contact time, $\mathrm{pH}$ and temperature using leaf, bark and seed of Moringa stenopetala adsorbents on $\mathrm{Ni}$ (II) removal in synthetic wastewater were obtained. At optimum experimental conditions the percent adsorption of synthetic wastewater sample was found to be 94,96 and 98 for leaf, bark and seed, respectively. From the adsorption models point of view the adsorption mechanism of nickel ion using bark and seed adsorbents was attributed to a physico-chemical adsorption process under the studied range of experimental parameters. The adsorption studies in industrial wastewater collected from Modjo Tannery Share Company reveal that for removal of $\mathrm{Ni}(\mathrm{II})$ $83 \%$ and $85 \%$ was found using bark and seed adsorbents of $M$. stenopetala tree, respectively. The method of adsorption developed in this study is cheap, fast and environmental friendly. 


\section{REFERENCES}

1. Egila, J.N.; Dauda, B.E.; Jimoh, T. J. Bio-Technol. 2010, 9, 8192.

2. Senthil, P.K.; Ramak, R.K.; Dinesh, K.S.; Sivanesan, S. J. Chem. Eng. 2010, 27, 347.

3. Olayinka, O.; Oyedeji, O.; Oyeyiola, O. J. Environ. Sci. Technol. 2009, 3, 286.

4. Prem, P.V.; Kallash, P.Y.; Vishwanath, S. J. Eng. and Technol. 1989, 3, 357.

5. Masood, A.; Mohd, A.; Sumbul, R. J. App.Sci. 2009, 2, 791.

6. Sarkar, M.; Acharya, P.K. Waste Managt. 2006, 26, 559.

7. Zvinowanda, C.; Okonkwo, J.; Shabalala, P.; Agyei, N. J. Environ. Sci. Technol. 2009, 6, 425.

8. Sajidu, S.M.; Henry, E.M.; Persson, T.; Masamba, W.R.; Kayambazinthu, L.D. J. Biotechnol. 2006, 5, 2397.

9. Mataka, L.M.; Sajidu, S.M.; Masamba, W.R.; Mwatseteza, J.F. J. Water Res. Environ. Eng. 2010, 2,50 .

10. Khataoon, S.; Anwar, J.; Hussan, M.; Fatima, H.; Khalid, H.; Ahmed, D. J. Sci. Res. 2009, 39, 41.

11. Matak, L.M.; Henry, M.T.; Masamba, R.L.; Sajidu, S.M. J. Environ. Sci. Technol. 2006, 3, 131.

12. Srivastava, V.C.; Swamy, M.M.; Mall, I.D.; Prasad, B.; Mishra, I.M. Physicochem. Eng Aspects 2006, 272, 89.

13. Akan, J.C.; Abdulrahman, F.I.; Dimari, G.A.; Ogugbuaja, V.O. J. Sci. Res. 2008, 23, 122.

14. Zawani, Z.; Luqman, C.; Thomas, S.; Choong, Y. J. Sci. Res.2009, 37, 67.

15. Theivarasu, C.; Mylsamy, S. J. Eng. Sci. Technol. 2010, 2, 6284.

16. Xiao, J.X.; Xue, J.M.; Tian, L.Z J. Hazard. Mater. 2010,175, 241.

17. Hardiljeet, K.B.; Meera, J.; Denis, M.O. J. Hazard. Mater. 2011, 186, 458.

18. Calero, M.; Hernáinz, F.; Blázquez, G.; Martín, M.; Tenorio, G. J. Chem. Eng. 2009, 26, 265.

19. Shama, S.; Moustafa, M.; Gadm, A. J. Electrochim. Acta 2010, 28, 125.

20. Abasi, C.Y.; Abia, A.A.; Igwe, J.C. J. Environ. Res. 2011, 5, 104.

21. Ratna, S.; Jagdish, V.; Balaji, R.; Madjeb, K.; Milind, B. J. App. Sci. 2010, 2, 260.

22. Michael, H.J. and Ayebaemi, I.S. Acta Chim. Slov. 2005, 52, 174.

23. Tariq, S.N. and Suhad, A.Y. J. Chem. 2009, 6, 153. 